\title{
Capripoxvirus Infections in Ruminants: A Review
}

\author{
Jihane Hamdi ${ }^{1, *}$, Henry Munyanduki ${ }^{2}{ }^{\infty}$, Khalid Omari Tadlaoui ${ }^{1}$, Mehdi El Harrak ${ }^{1}$ and Ouafaa Fassi Fihri ${ }^{3}$ \\ 1 Department of Research and Development, Multi-Chemical Industry Santé Animale, Lot. 157, Z I, \\ Sud-Ouest (ERAC) B.P., 278, Mohammedia 28810, Morocco; k.tadlaoui@mci-santeanimale.com (K.O.T.); \\ m.elharrak@mci-santeanimale.com (M.E.H.) \\ 2 Pirbright Institute, Ash Rd, Pirbright, Woking GU24 0NF, UK; Henry.Munyanduki@pirbright.ac.uk \\ 3 Department of Microbiology, Immunology and Contagious Diseases, Agronomic and Veterinary Institute \\ Hassan II, Madinat Al Irfane, Rabat 6202, Morocco; o.fassifihri@iav.ac.ma \\ * Correspondence: j.hamdi@mci-santeanimale.com
}

Citation: Hamdi, J.; Munyanduki,

H.; Omari Tadlaoui, K.; El Harrak, M.; Fassi Fihri, O. Capripoxvirus Infections in Ruminants: A Review. Microorganisms 2021, 9, 902. https://doi.org/10.3390/ microorganisms 9050902

Academic Editor: Shawn Babiuk

Received: 27 February 2021

Accepted: 30 March 2021

Published: 23 April 2021

Publisher's Note: MDPI stays neutral with regard to jurisdictional claims in published maps and institutional affiliations.

Copyright: (c) 2021 by the authors. Licensee MDPI, Basel, Switzerland. This article is an open access article distributed under the terms and conditions of the Creative Commons Attribution (CC BY) license (https:// creativecommons.org/licenses/by/ $4.0 /)$.

\begin{abstract}
Lumpy skin disease, sheeppox, and goatpox are notifiable diseases of cattle, sheep, and goats, respectively, caused by viruses of the Capripoxvirus genus. They are responsible for both direct and indirect financial losses. These losses arise through animal mortality, morbidity cost of vaccinations, and constraints to animals and animal products' trade. Control and eradication of capripoxviruses depend on early detection of outbreaks, vector control, strict animal movement, and vaccination which remains the most effective means of control. To date, live attenuated vaccines are widely used; however, conferred protection remains controversial. Many vaccines have been associated with adverse reactions and incomplete protection in sheep, goats, and cattle. Many combinationand recombinant-based vaccines have also been developed. Here, we review capripoxvirus infections and the immunity conferred against capripoxviruses by their respective vaccines for each ruminant species. We also review their related cross protection to heterologous infections.
\end{abstract}

Keywords: capripoxvirus; live; inactivated; combined; vaccines; cross protection

\section{Introduction}

Sheeppox, goatpox, and lumpy skin disease (LSD) are notifiable diseases of cattle, sheep, and goats, respectively. Their causative agents are viruses belonging to the Capripoxvirus genus of the Poxviridae family [1]. They are economically important because they cause fever, emaciation, weight loss, drop in milk production, and skin damage [2].

The three viruses are endemic in Africa, Middle East, central Asia, and the Indian subcontinent. LSD is also present in many parts of Europe, the Balkans (namely Bulgaria, Serbia, and Albania) [3], and in 2019, incursions of LSD into India, China, and Bangladesh were reported (Figure 1) [4].

Capripoxviruses have the characteristic of using direct or indirect means to infect their hosts. Transmission can occur either by direct contact, through aerosols released by infected hosts, or indirectly, through the environment and infected vectors [5]. However, the routes of transmission can vary from virus to virus, even within the same genus [6]. The sheeppox (SPV) and goatpox (GPV) viruses are mainly found in oral, nasal, or ocular secretions, and transmission between animals occurs by direct contact through inhalation of aerosols or by indirect transmission $[7,8]$ ). For the LSD virus, authors report mainly mechanical transmission by insects such as Aedes aegypti mosquitoes, ixodid ticks, Stomoxys calcitrans, and the tabanids Haematopota spp. [9-14].

Clinical signs of Capripoxvirus diseases are variable depending on the individual host's susceptibility, the virus species, and virulence of the viral strain. These can be mild, severe, or sometimes fatal. Usually, signs include fever, enlarged lymph nodes, oculonasal discharge, and eruption in the skin and mucous membranes [15-17]. 


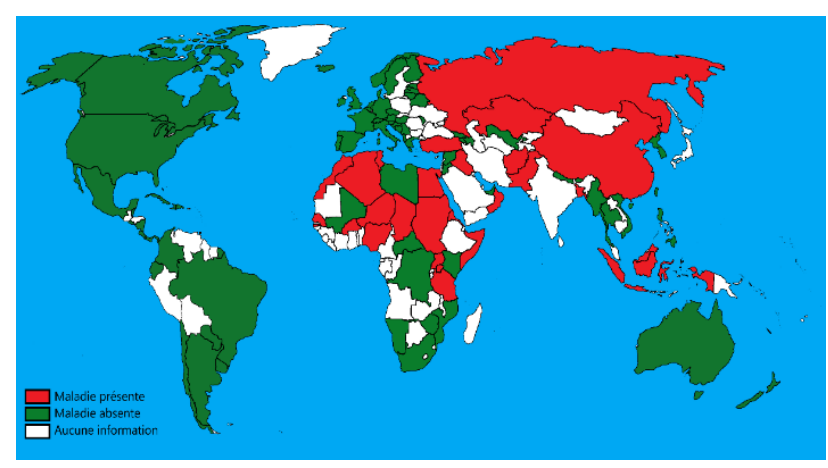

(A)

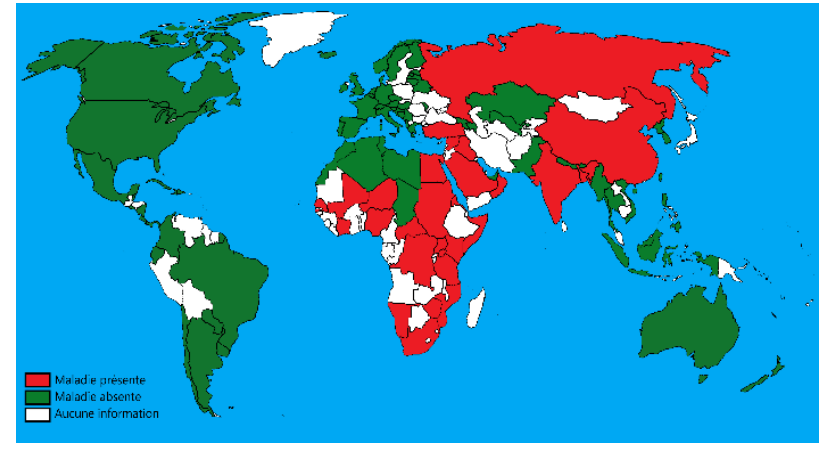

(B)

Figure 1. (A): Geographical distribution of sheeppox; (B): geographical distribution of lumpy skin disease (Adapted from World Animal Health Information Database (WAHIS), 2020). Green: absence of the disease; red: presence of the disease; white: unavailable data.

Control and eradication of diseases due to capripoxviruses depend on vector control, early detection of outbreaks, restrictions on animal movement, and vaccination [18]. Attenuated vaccines are mainly used and commercially available; however, the conferred protection remains controversial because these vaccines may be ineffective or cause mild reactions [19-21]). Inactivated vaccines are safe, stable, and allow combinations with other antigens to make polyvalent vaccines, and they can be applied in disease-free countries. Even though a few inactivated capripoxvirus vaccines exist, sheeppox and LSDV vaccine were shown to offer full protection against their respective virulent challenge strains [22-24]. Combined SPV/GPV vaccines with other antigens have been reported to protect small ruminants against two infections. Recombinant capripoxvirus-vectored vaccines are also reported in the literature.

Here, we review the capripoxvirus immunity and protection conferred by different available vaccines.

\section{Importance}

The three diseases of the Capripoxvirus genus are economically important and classified by the World Organisation for Animal Health (OIE) as notifiable diseases because of their rapid spread and the significant economic losses they can cause. The three viruses also present obstacles to genetic improvement in small ruminants and cattle breeding.

Sheeppox and goatpox cause annual losses associated with a decrease in milk production and weight gain, damage to wool and hides, and high mortalities in lambs and kids $[3,25])$. In a study conducted in India, Garner et al. (2000) estimated income losses up to $30-43 \%$ of the total annual revenue and reported that the recovery of a herd from an epidemic may take up to six years [26].

Vaccination campaigns, restrictions on animal movements, and restrictions on the trade of live animals or their products also contribute to significant financial losses.

The lumpy skin disease attack rate is around $10 \%$ in endemic areas; however, it can reach $85 \%$ in an affected herd if no preventive measures are applied [27]). The impact of the disease is significant during peak lactation due to fever and secondary mastitis in infected animals [3]. Deep lesions recorded in the skin leave permanent scars which reduce the quality of skins destined for the leather industry [28]. Cattle rearing for slaughter is also affected due to wasting and long convalescence of infected cattle [29]. The control procedures in the event of a disease outbreak, the quarantine of neighbouring farms, and the costs borne by the breeders in the control of the disease are additional costs that impact the economy $[30,31]$. Internationally, LSDV epidemics result in restrictions in the cattle trade and can cause considerable losses [32]. Restrictions apply to live animals, meat, leather, and dairy products [31]. 
In addition, capripox diseases are restrictive for genetic improvement of livestock because high-milk producing cattle are more severely affected by the infection, compared to local breeds $[3,33]$.

\section{Aetiology}

Sheeppox, goatpox, and lumpy skin disease of cattle result from infection by SPV, GPV, and LSDV which are members of Capripoxvirus genus within Poxviridae family [6]. Even though they are serologically indistinguishable, they may be differentiated using molecular analysis $[28,34,35]$.

Poxviruses are ovoid-shaped and characterised by a complex structure. They are 300 to $400 \mathrm{~nm}$ long [36] and can be identified using electron microscopy [37]. The virion takes the form of a central core containing the genome and the various viral proteins. The core and the two lateral bodies are surrounded by a capsid [38,39].

As they appeared thousands of years ago, poxviruses have seen their genomes evolve by the gain or loss of genes through duplication and horizontal transfer of genes [40-42]. Capripoxviruses are double-stranded DNA viruses whose ends are covalently linked to form a hairpin structure [43]. The central region of the genome contains conserved genes which encode viral replication and structural protein synthesis. Regions at the ends, called inverted terminal repeat sequences (ITR), are made up of non-essential genes involved in virulence [44].

Capripoxviruses genomes contain a high percentage of adenine and thymine [45] and share 147 putative genes which encode proteins of 53 to 2027 amino acids (AA). These proteins are involved in replication, structure, virulence, and host range functions. The molecular analysis of the three capripoxviruses has been studied by several authors. Tulman et al. (2002) sequenced and analysed the complete genomes of several strains of SPV, GPV, and LSDV and reported the presence of an ancestral virus, related to LSDV [46]. Biswas et al. (2019) analysed 36 different strains and found a loss of 5 Open Reading Frames (ORF) in the SPV/GPV lineage [35]. Additionally, Rouby et al. (2018) [47] reported deletion of 21 nucleotides in the RPO30 gene of SPV, while the analysis of a partial fragment of the B22R gene showed a deletion in the SPV Romania strain, compared to GPV and LSD (Chibssa et al., 2019) [48]. These findings have confirmed that GPV is more closely related to LSDV than SPV $[49,50]$.

\section{Clinical Signs}

The incubation period is 4 to 8 days for SPV and 4 to 15 days for GPV and LSD. After its entry into the host, the virus replicates in the tissues. It is localised in the lymph nodes three to four days after a primary viraemia. The virus then spreads throughout the body and affects the liver, lungs, and spleen. Nodules appear 7 to 19 days post-infection. After the appearance of skin lesions in affected animals, they may develop conjunctivitis, rhinitis, and lymphadenopathy, in the prescapular lymph nodes. Excessive salivation can occur after an infection [17].

The clinical signs of SPV and GPV are similar and can be mild or severe, sometimes fatal. They are variable depending on the individual susceptibility of the host and the viral strain; varying degree of severity has been reported in goats of same age and breed, infected with the same strain [15]. The diseases are more serious in young animals than in adults which usually have a mild form. These signs usually include fever, which can reach 40 to $42{ }^{\circ} \mathrm{C}$, enlarged lymph nodes, oculonasal discharge, and damage to the skin and mucous membranes. Skin lesions usually begin as erythematous macules that harden to form papules measuring between 0.5 to $1.5 \mathrm{~cm}$ in diameter which are usually devoid of fluid. The papules then form pustules and scabs following the necrosis of tissues [51]. These lesions are most often found in hairless areas of the animal's body such as the armpits, face, ears, eyelids, and inguinal area, but they can spread all over the body in severe cases [52]. On the mucous membranes, especially on the mouth, nostrils, eyes, vagina, and foreskin, the lesions can ulcerate or necrose. These lesions cause a lack of appetite, ptyalism, and 
mucopurulent discharge. Lesions in the eyes and eyelids can cause conjunctivitis and blepharitis. Damage to the intestinal tract or respiratory system can lead to diarrhoea, emaciation, or coughing, and abortion and pneumonia can also occur.

In the benign form, the lesions are rather localised under the tail or at the level of the ears. Lesions are visible to the naked eye but may also require palpation, especially in animals with thick fleece. Skin lesions are slow to heal and can cause permanent scarring. They can also be accompanied by bacterial complications or myases [53]. A nodular form, called 'stone pox', has also been described [51]. It consists of the appearance of nodules all over the thickness of the skin, which eventually become necrotic. After necrosis, the nodules break off and leave ulcerative lesions or scabs that heal [51].

Lumpy skin disease is characterised by the appearance of localised or generalised nodules, with deterioration of the general condition depending on the severity of the disease. Natural resistance to LSDV has been reported in cattle. In experimental infections, only half or two-thirds of infected animals may show clinical symptoms of the disease, although all animals are viraemic [3,54,55]. Gari et al. (2015) and Hamdi et al. (2020) also described the development of clinical disease in only three out of five challenged control animals during their experiments [56,57].

The disease manifests as a biphasic febrile syndrome with a peak a few days after infection and a second at day 10 post-infection. During this phase, the animals generate salivary, nasal, and lacrimal secretions and eye disorders. Lymphadenopathy is particularly observed in the subscapular and precrural lymph nodes. A second febrile syndrome appears for 4 to 10 days after the first and is accompanied by skin nodules, pathognomonic signs of the disease [31]. The classic form is characterised by hyperthermia and localised or disseminated nodules on the skin, accompanied by respiratory disorders, adenomegaly anorexia, and dysgalactia. Lesions on the skin appear as macules that turn into papules and then into hard, rounded, painless nodules. These nodules vary in size between 0.5 and $5 \mathrm{~cm}$ in diameter. Their number varies from 1 to 100 nodules, and they are localised on the face, the neck, the limbs, the flanks, the udder and its teats, the scrotum, the perineum and on the oral, nasal, ocular, vulvar mucous membranes or foreskin [58]. The nodules resorb and scar, which leads to leather depreciation. This form is accompanied by conjunctivitis and keratitis which can progress to blindness [58]. Reproduction and milk production are affected and abortions are also common [59].

In the mild form, cattle exhibit small nodules that heal quickly with scarring in three to six weeks, without affecting the general condition. The nodules are perceptible to the touch or spotted in the hairless areas of the bovine (at the level of the vulva, the udder, the muzzle, and the perineum).

\section{Immunity}

The immune response to an infectious agent is characterised by the coexistence of innate and adaptive immunity and is particularly complex in poxvirus infections. Each component of the immune system plays a vital role in the segregation and elimination of the virus [60].

Innate immunity occurs early and comprises anatomic, physiologic, endocytic, and inflammatory barriers [61]. It relies on the interaction between pattern recognition receptors (PRRs) and pathogen-associated molecular patterns (PAMPs) and serves as the first line of defence to the pathogen. The PRRs are expressed in numerous cells including phagocytes (macrophages and neutrophils), dendritic cells, mast cells, basophils, eosinophils, innate lymphoid cells, and natural killer (NK) cells which produce interferon gamma [60]. Unlike the role of cellular immunity and of antibodies, the role of these cells has not been fully described in capripoxviruses [31].

The immune response is subsequently adaptive and includes B cells and $\mathrm{T}$ cells. In the orthopoxvirus group, humoral immunity has been reported to confer protection from reinfection against poxviruses, while poxvirus clearance is induced by both humoral and cellular responses [3,62]. B cells are responsible for humoral-mediated immunity-they 
recognise the antigen, produce specific antibodies, and can also act as Antigen-presenting cells (APC) $[63,64]$. While the humoral-mediated immunity is known to provide protection against capripoxviruses, it has been reported that only $34 \%$ to $65 \%$ of cattle produce antibodies following vaccination with live attenuated LSD vaccine $[23,65,66]$. It has also been reported that small ruminants could be protected against capripoxvirus even with a neutralisation index below $0.5 \log _{10}$ and no precipitating antibodies [67]. However, although circulating antibodies may limit the spread of the virus, they do not prevent replication of the virus at the site of infection [68].

These findings indicate that cell-mediated immune response is of importance in poxvirus infection and is necessary at the early stage of infection [69].

Cell-mediated immunity is crucial against capripoxvirus infections and contributes significantly to the protection of the host $[3,70,71]$. The most important role is played by $\mathrm{T}$ cells, which are produced in the bone marrow and complete their maturation in the thymus. They require the action of APCs to recognise a specific antigen, unlike B cells [72,73]. Although T cells are differentiated into poxvirus-specific cytotoxic T (LT) cells (CD8+) and helper (LTh) cells (CD4+) (which are important for the maturation of B cells), their role in protection against capripoxviruses has not completely been elucidated [3]. Their contribution to immunity against other poxviruses such as ectromelia, monkeypox, and vaccinia viruses has been studied in mice, rhesus macaques, and humans [74-77]. Some authors also reported the development of generalised vaccinia in individuals with abnormalities of T-cell function, in an immunocompromised individual, whilst patients with congenital agammaglobulinemia did not develop the disease [78-80]. The induction of cell-mediated response is dependent on the immunological status of the individuals. The T-cell response occurs earlier in non-naïve than in naïve persons, due to the presence of memory T cells [81]. T-cell immunity remains stable for decades; some authors reported a decrease of T cells 8 to 15 years after vaccination against smallpox [82], while others reported the presence of T-cell memory of up to 30 years after vaccination [83]. B-cell memory to smallpox has been reported to persist for 50 to 90 years after vaccination $[82,84,85]$.

The passive transfer of maternal capripoxvirus antibodies has been investigated by several authors. Agianniotaki et al. (2018) [86] detected antibodies in calves after feeding with colostrum until three months of age, and Milovanovic et al. (2019) [65] showed, through Indirect Fluorescent Antibody Test (IFAT), Virus Neutralization Test (VNT), and Enzyme-linked Immunoassay (ELISA), that cows provide colostral antibodies to their calves. Weiss (1968) also reported the persistence of antibodies in calves after colostrum feeding for up to six months [87]. In sheep, the presence of maternal antibodies has been detected in lambs from ewes vaccinated with SPPV vaccine [88,89], and in a challenge trial with the Romania strain, it has been reported that all lambs born displayed neutralising antibodies [90].

Capripoxvirus antigens involved in the humoral response are not known; however, studies on orthopoxviruses showed the presence of nine specific B-cell epitopes. Five of these, namely, H3, B5R, A27, D8, and L1R, induced protective neutralising responses and one-A33-induced protection with non-neutralising antibodies in mice against vaccinia virus $[3,62,91-93]$.

\section{Vaccination against Capripoxviruses}

Control and eradication of capripoxvirus infections depend on veterinary services, farm holders' sensitisation, and early detection of disease in a geographic area. The control also requires the slaughter of infected animals, monitoring of movements, and establishment of a quarantine system [3,94]. Vaccination remains the best way to control infection and transmission of capripoxviruses; however, there are factors that can affect its effectiveness. Vaccination during an epidemic, the reuse of needles, improper administration of the vaccine, and disruption of the cold chain can affect the protection conferred by the administered vaccine $[31,95,96]$. 
Live attenuated vaccines are mostly used to control capripoxvirus infections [31]. Several strains of SPV/GPV are cited in the literature. They are named on the basis of the place of isolation (Jaipur [97], Uttarkashi [98], Romania [88], Cairo [94], Chinese, etc). These strains have been attenuated by passages through different cell culture systems or on embryonated eggs $[99,100]$ (Table 1$)$.

Table 1. Capripoxvirus strains reported in the literature.

\begin{tabular}{|c|c|c|c|c|}
\hline Isolate/Strain & Origin & Cells & Passages for Attenuation & Reference \\
\hline SPV RM65 & Sheep & Sheep kidney cells & 30 & [101] \\
\hline SPV Romania & Sheep & Lamb kidney cells & 40 & [88] \\
\hline SPV Bakirkoy & Sheep & Calf kidney cells & 32 & [102] \\
\hline SPV Rumania Fanar & Sheep & Lamb testis & 26 & [103] \\
\hline SPV Perego & Sheep & Lamb testis and calf kidney & $\begin{array}{l}11 \text { times in lamb testis and } \\
10 \text { times in calf kidney }\end{array}$ & [104] \\
\hline SPV Ranipet & Sheep & Sheep thyroid cells & 35 & [105] \\
\hline GPV Gorgan & Goat & Kid kidney cortex cells & - & [106] \\
\hline GPV Uttarkashi & Goat & $\begin{array}{c}\text { Primary lamb testis cells and } \\
\text { Vero cells }\end{array}$ & $\begin{array}{c}34 \text { on primary cells and } 26 \\
\text { on Vero }\end{array}$ & [107] \\
\hline GPV Mysore & Goats & Primary lamb testis cells & 25 & [108] \\
\hline GPV Kedong & Sheep & Lamb testis cells & - & [109] \\
\hline GPV Isiolo & Sheep & Lamb testis cells & - & [109] \\
\hline LSD KSGP O 180 & Sheep & Bovine foetalmuscle cells & 18 & [110] \\
\hline LSD KSGP O 240 & Sheep & Lamb testis cells & $13-27$ & [111] \\
\hline LSD Neethling & Cattle & $\begin{array}{l}\text { Lamb kidney cells and } \\
\text { chorioallantoic membranes (CAM) }\end{array}$ & $\begin{array}{c}61 \text { on primary cells and } 20 \\
\text { on CAM }\end{array}$ & [99] \\
\hline
\end{tabular}

Sheep are mostly vaccinated with Romania, Bakirkoy, Yugoslavian RM65, KSGP O 240, and KSGP O 180 strains, goats with Gorgan, Mysore, Uttarkashi, and KSGP O 240 strains, while cattle are vaccinated with Neethling, KSGP O 240 and KSGP O 180, Romania, Bakirkoy, and Gorgan strains.

In North Africa and the Middle East, the Romania strain is mostly used to protect sheep, while in East Africa, the KSGP O 240 and KSGP O 180 are commonly used. In Turkey, vaccination of sheep is conducted using the Bakirkoy strain, while Iran uses the RM65 strain [112-115].

The attenuated Gorgan strain is used in Iran and the Middle East to protect against goatpox infection, while in India, vaccination is carried out using Uttarkashi and Mysore strains of caprine origin $[106,107,116]$.

The KSGP O 240 vaccine is mainly used against SPV and GPV in East Africa, although molecular characterisation has identified it as an LSD virus $[49,117,118]$. This vaccine, developed by Davies (1976) [111], has been tested in sheep and goats and have been shown to be protective against both SPV and GPV virulent strains [112]. Additionally, the two strains-KSGP O 240 and KSGP O 180 (Kenyan origin)—have been used for a long time against capripoxviruses, especially against SPV. However, molecular characterisation using the RPO30 and GPCR genes of both strains revealed that they were actually LSDV strains [118]. Both strains have been successfully used for years in small ruminants.

To protect cattle against LSD, the Neethling strain is the most commonly used worldwide in endemic countries. The strain has been attenuated by 61 serial passages of a field isolate and then through 20 passages on the chorioallantoic membrane (CAM) and three passages on renal primary cells. The strain was then passed 10 times on Madin Darby Bovine Kidney (MDBK) cells, then five times in primary bovine testis cells by Weiss 
$(1968)[87,99,119]$. In addition to the original Neethling strain, other derivative strains with similar sequences (99\% homology) were used as commercial vaccines [120] The Neethling strain has been shown to be effective in cattle; however, it can cause adverse inflammation at the injection site, accompanied by fever and decreased milk production [121]. The strain can also cause symptoms similar to the disease with lower intensity, called 'Neethling disease'. Several studies have reported the development of adverse reactions after the vaccination of cattle against LSDV. According to Ben-Gera et al. (2015) [21], the LSD Neethling vaccine administered to cattle induced adverse effects with a very low incidence $(0.38 \%)$. In Croatia, a free-disease country, the vaccine exhibited adverse effects in $0.09 \%$ of vaccinated cattle [122]). As these effects have been reported by breeders, the data can be underreported [123]. Agianniotaki et al. (2017) [124] were able to identify the vaccine virus in cattle vaccinated with Neethling strain that showed mild clinical signs of LSDV. Collected nodules, mainly from the head and neck, were smaller and more superficial than those found in animals infected with virulent LSDV and were not accompanied by fever, discharge, and enlarged lymph nodes that characterise the disease. Similarly, in a study in Greece carried out by Katsoulos et al. (2018) [121], skin lesions in the form of small nodules $(<0.5 \mathrm{~cm})$ were observed in 19 among 215 vaccinated animals. Bedekovic et al. (2017) [125] were able to detect the vaccine virus in the nodules, blood, and milk of cattle vaccinated with Neethling vaccines.

Two strains-KSGP O 240 and KSGP O 80-have also been used to protect cattle against LSD in the horn of Africa and Israel. Poor protection was induced when used in cattle and widespread pathognomonic reactions to LSD were reported in dairy cattle vaccinated with KSGP strain O-240 [20,126]. Salib and Osman (2011) [127] reported that an LSD epidemic occurred in Egypt although cattle were vaccinated with the KSGP O-240 vaccine. Similarly, in Ethiopia, a morbidity rate of $22.9 \%$ was reported in cattle vaccinated with the same strain [20]. However, the vaccine failure could be linked to insufficient vaccination coverage and the quality of vaccines [31]. The onset of the disease in cattle following vaccination with the KSGP strain could be explained by the insufficient attenuation of strains used. The KSGP O-180 strain was attenuated by 18 passages on muscle cells, while the KSGP O-240 strain was attenuated by only six passages $[3,110,128]$.

In general, homologous vaccines offer good protection and are able to control the diseases when vaccination coverage reaches 75\% [123]. Depending on the strain and the animal sensitivity, neutralising antibodies appear 14 days post-infection or vaccination and peaks between 28- and 35-days post-vaccination. Vaccinated animals can be protected even when antibodies are no longer detectable because of the dominance of cell-mediated immunity.

There is little information regarding the duration of immunity to capripox vaccines. Some authors report protection for at least two years after immunisation with live vaccines against SPV [105,116,129]; others have been able to demonstrate protection against challenge with goatpox virus more than four years after vaccination [130].

Few inactivated vaccines have been developed to protect areas at risk or in case of incursion in a free-disease country. The protection conferred with inactivated capripoxviruses has been described by Awad et al. (2003) as 'non-solid and of short duration', requiring a booster every six months [131]. More recent studies, however, showed complete protection after the challenge and persistence of antibodies for a longer time period. In a sheep study, a group of 16 sheep was immunised with an inactivated and live attenuated vaccine. The animals were monitored for serological responses and challenged with a virulent strain. All vaccinated sheep were protected against experimental infection and developed antibodies that lasted up to nine months post-vaccination [22]. In a cattle experiment, cattle were immunised using the inactivated Neethling vaccine. A high percentage of reactors had antibodies elicited and protected cattle against challenge. The vaccine was also tested in the field and showed at least $80 \%$ seroconversion [23]. A second LSD inactivated vaccine was tested recently in cattle and showed complete protection against challenge [24]. 
The low vaccination coverage is linked to poor infrastructure with limited access to flocks. It has been reported that the use of a bivalent vaccine that protects against two infections in one injection would minimise the cost of vaccination, overcome the constraints of multiple injections, and allow a large vaccination coverage. Among the combined vaccines that have been developed, a formalin-inactivated SPV vaccine with vaccination against anthrax and clostridium infections has been tested [132]. In another assay, the SPV vaccine was combined with anthrax [133]. Recently, many authors developed and tested the combination of SPV with Peste des Petits Ruminants (PPR) against both diseases. The SPV-PPR combined vaccines have been subsequently used at a large scale in Morocco and other African countries [113,134-136].

The use of poxviruses as vaccine vectors in recombinant vaccines presents many advantages such as the large size of the viral genome (140-300 kbp) which can contain up to 25,000 bases of foreign DNA, their thermal stability, and their replication in the cytoplasm of infected cells without integration into the host genome. Several recombinant capripoxvirusvectored vaccines have been generated using genes of Rift Valley fever $[137,138]$, peste des petits ruminants [139-142], rinderpest [143], bluetongue [144,145]), foot-and-mouth disease virus Mp1-2A polyprotein [146], EG95 antigens from Echinococcus granulosus [147], and OMP25 outer membrane protein from Brucella [148]. Developed recombinant capripox vaccines have not yet been used at a large scale in the field despite having the ability to differentiate them between infected and vaccinated animals (DIVA).

Different techniques are used to evaluate post-vaccination response. The humoral response is investigated by VNT and ELISA, which could be used for mass screening $[65,149,150])$. However, only a challenge can determine the protection against infection with a capripox [67]. The immunoperoxidase assay has also been developed for the detection of antibodies against LSDV, SPPV, and GTPV [151]. Other techniques such as Western Blot, counter-immunoelectrophoresis test (CIE), or agar gel precipitation test have also been described for the detection of anti-capripox antibodies [152]. The evaluation of the cell-mediated response is carried out by the lymphocyte proliferation is carried through MTT (3-(4,5-dimethylthiazol-2-yl)-2,5-diphenyltetrazolium bromide) technique and by mRNA cytokine expression of which IFN- $\gamma$ and IL-4 are the most important against Capripoxvirus infection $[70,71]$.

Since the three members of the genus Capripoxvirus present no serotypes and are genetically similar, it has been suggested the development of a universal vaccine to protect against the three viruses $[116,153]$. Thus far, there is no consensus on a universal vaccinesome strains can protect one species and induce lesions in another, and some are fully protective in homologous species and partially protective in other species (Table 2).

The lack of protection of SPV vaccines against goatpox has previously been reported by Prasad and Datt (1973) using SPV [159]. In Saudi Arabia, Abuelzein et al. (2003) [160] reported the appearance of the disease in goats vaccinated with SPV Romania vaccine locally produced; however, few data on vaccination coverage and vaccination conditions were presented. Although no challenge was performed, Abdelfatah et al. (2019) detected a satisfactory level of peripheral blood mononuclear cells (PBMCs) and lymphocytes in goats vaccinated with the Romania strain [158]. In a recent paper, Hamdi et al. (2020) established full protection of goats against the Romania strain in an experimental goatpox infection [57].

The use of SPV-based vaccines to protect cattle against LSV has been documented in Africa and the Middle East based on field observations. Studies carried out in Israel with RM65 strain demonstrated lower protection in cattle when vaccinated with the sheep dose [156] or at 10-times the sheep dose [21] when compared to the Neethling vaccine. In Jordan, a vaccination campaign was conducted in cattle using a vaccine based on the RM65 strain. The vaccine caused fever, reduced milk production, and the development of nodules in vaccinated cattle [161]. In Turkey, Sevik and Dorgan (2016) reported LSD vaccination failure with SPV Bakirkoy strain, at 3-4 times the sheep dose [115]. In Egypt, vaccination against LSDV in cattle was carried out with SPV Romania strain; however, cases 
of infection emerged in vaccinated herds as reported by Ali et al. (1990) [162], Abdallah et al. (2018) [163], and Zeedan et al. (2019) [164].

Table 2. Conferred protection by capripoxvirus vaccines.

\begin{tabular}{|c|c|c|c|c|}
\hline \multirow{2}{*}{ Vaccine/Strain } & \multicolumn{3}{|c|}{ Safety and Protection } & \multirow{2}{*}{ Reference } \\
\hline & Sheep & Goat & Cattle & \\
\hline GPV Gorgan & Safe, partially protective & Safe and protective & Safe and protective & {$[56,106,154]$} \\
\hline GPV Mysore & - & Safe and protective & - & [108] \\
\hline GPV Uttarkashi & - & Safe and protective & - & [107] \\
\hline GPV Kedong and isiolo & - & - & Safe and protective & [155] \\
\hline SPV RM65 & Safe and protective & - & Partially protective & {$[21,156]$} \\
\hline SPV Perego & Safe and protective & - & - & {$[103,157]$} \\
\hline SPV Rumania Fanar & Safe and protective & - & - & \\
\hline SPV Romania & Safe and protective & Safe and protective & Partially protective & {$[57,158]$} \\
\hline SPV Bakirkoy & Safe and protective & - & Partially protective & {$[102,115]$} \\
\hline LSD Neethling & Partially protective & - & $\begin{array}{l}\text { Causes Neethling } \\
\text { disease, protective }\end{array}$ & {$[23,57]$} \\
\hline LSD KSGP 0180 & Safe and protective & Safe and protective & Safe and protective & [110] \\
\hline LSD KSGP 0240 & Safe and protective & Safe and protective & $\begin{array}{l}\text { Residual virulence, } \\
\text { partial protection }\end{array}$ & {$[20,112,126,127]$} \\
\hline
\end{tabular}

Investigations on the response of cattle vaccinated with Romania strain showed proliferation of lymphocytes and stimulation of gamma interferon and interleukin 4; however, no challenge has been conducted to test the efficacy of the vaccine [70,71,165]. Mikhael et al. (2016) observed, through serology and hypersensitivity testing, that the conferred protection by SPV Romania in cattle was insufficient [166]. In another study, Mikhael et al. (2017) tested a bivalent SPV Romania and GPV vaccine in cattle and assessed the humoral response by seroneutralisation, ELISA, and the cellular responses by stimulation of lymphocytes [167]. The authors concluded that the bivalent vaccine induced a better response than the monovalent Romania vaccine but recommended the use of a homologous strain. Similar results were reported by Aboul Soud et al. (2018) [168], who demonstrated that no serological response was induced in cattle vaccinated with the Romania strain, while a trivalent capripox vaccine (composed of SP Romania, GPV Held, and KSGP 0180) induced antibodies in $66 \%$ of vaccinated animals. In a recent experiment, partial protection was obtained in cattle vaccinated with Romania strain, no serology detected and at challenge, three out of seven vaccinated cattle showed viraemia and clinical signs similar to control animals [57].

The Gorgan goatpox strain was also tested in sheep, compared to the SPV vaccine at different doses, and challenged with a virulent SPV strain. Only sheep vaccinated with the SPV vaccine were protected and the authors, therefore, concluded that the Gorgan strain was unable to induce effective immunity in sheep against SPV infection [154].

In cattle, several studies showed the effectiveness of GPV strains to protect cattle against LSD. The Kedong and Isiolo strains, isolated in sheep in 1950 and identified as goatpox viruses [118], were able to protect vaccinated cattle against challenge [109]). The Gorgan strain, commonly used in Iran for vaccination against LSD, was tested in comparison with the KSGP O-180 strain and the Neethling strain in cattle. The Gorgan strain was more immunogenic than the two other strains at challenge [56]. However, the authors recommend undertaking large-scale studies to confirm their findings. Varshovi et al. (2017) [71] investigated humoral and cellular response in cattle after vaccination with Gorgan strain and found it immunogenic. In a recent experiment, complete protection in 
cattle was obtained by Zhugunissov et al. (2020) against challenge after the use of Gorgan strain at 10 times goat dose [169].

LSD vaccine based on Neethling has been used to protect sheep against SPV by Hamdi et al. (2020b); the authors report partial protection against virulent SPV challenge [57].

It appears that the consensus on one universal vaccine against the three capripoxvirus infections is not realistic. In addition, the geographic distribution of diseases is different. Thus, in some countries, the presence of SPV / GPV may or may not be accompanied by that of LSDV [2]. For instance, in North Africa, SPV is endemic, while no cases of LSD or GPV were reported. In southern Africa, LSD is endemic; however, SPV and GPV are absent. The European continent is free from GPV and SPV (except in Greece where outbreaks of SPV are still notified), while LSD has been reported in many countries of southeastern Europe. In the Middle East, central and eastern Asia, the three diseases are endemic. The use of a vaccine containing a virus not circulating in the country is not indicated [27].

Capripoxvirus infections are emerging diseases that represent a threat to ruminant industry farming in large geographical areas. Mixed flocks of sheep, goats, and cattle living in proximity is a common occurrence in endemic countries, and vaccination should be carried out systematically using the homologous vaccine, live or inactivated according to the epidemiological situation.

Author Contributions: J.H. drafted the manuscript, H.M. and O.F.F. reviewed the manuscript, K.O.T. and M.E.H. participated in the design and the follow-up of the review. All authors have read and agreed to the published version of the manuscript.

Funding: This research did not receive any specific grant from funding agencies in the public, commercial, or not-for-profit sectors.

Acknowledgments: The authors gratefully acknowledge the support for this study by MCI Santé Animale.

Conflicts of Interest: The authors declare no conflict of interest.

\section{References}

1. OIE. Sheep Pox and Goat Pox. Manual of Diagnostic Tests and Vaccines for Terrestrial Animals. Chapter 3.7.12. 2018. Available online: https:/ / www.oie.int/fileadmin/Home/eng/Animal_Health_in_the_World/docs/pdf/Disease_cards/SHEEP_GOAT_ POX.pdf (accessed on 10 February 2021).

2. Babiuk, S.; Bowden, T.R.; Boyle, D.B.; Wallace, D.B.; Kitching, R.P. Capripoxviruses: An Emerging Worldwide Threat to Sheep, Goats and Cattle. Transbound Emerg. Dis. 2008, 55, 263-272. [CrossRef] [PubMed]

3. Tuppurainen, E.S.M.; Venter, E.H.; Shisler, J.L.; Gari, G.; Mekonnen, G.A.; Juleff, N.; Lyons, N.A.; De Clercq, K.; Upton, C.; Bowden, T.R.; et al. Review: Capripoxvirus Diseases: Current Status and Opportunities for Control. Trans. Emerg. Dis. 2017, 64, 729-745. [CrossRef] [PubMed]

4. World Animal Health Information Database (WAHIS). 2020. Available online: https://www.oie.int/wahis_2/public/wahid. $\mathrm{php} /$ Diseaseinformation/Diseasetimelines (accessed on 26 October 2020).

5. Sprygin, A.; Pestova, Y.; Wallace, D.B.; Tuppurainen, E.; Kononov, A.V. Transmission of Lumpy Skin Disease virus: A short review. Virus Res. 2019, 269, 197637. [CrossRef] [PubMed]

6. Buller, R.M.; Arif, B.M.; Black, D.N.; Dumbell, K.R.; Esposito, J.J.; Lefkowitz, E.J.; McFad-den, G.; Moss, B.; Mercer, A.A.; Moyer, R.W.; et al. Family Poxviridae. In Virus Taxonomy: Classification and Nomenclature of Viruses. Eighth Report of the International Committee on Taxonomy of Viruses; Fauquet, C.M., Mayo, M.A., Maniloff, J., Desselberger, U., Ball, L.A., Eds.; Elsevier: Amsterdam, The Netherlands, 2005; pp. 117-133.

7. Kitching, R.P.; Mellor, P.S. Insect transmission of capripox virus. Res. Vet. Sci. 1988, 40, 255-258. [CrossRef]

8. Bowden, T.R.; Babiuk, S.L.; Parkyn, G.R.; Copps, J.S.; Boyle, D.B. Capripoxvirus tissue tropism and shedding: A quantitative study in experimentally infected sheep and goats. Virology 2008, 371, 380-393. [CrossRef] [PubMed]

9. Chihota, C.M.; Rennie, L.F.; Kitching, R.P.; Mellor, P.S. Mechanical transmission of Lumpy Skin Disease virus by Aedes aegypti (Diptera: Culicidae). Epidemiol. Infect. 2001, 126, 317-321. [CrossRef] [PubMed]

10. Chihota, C.M.; Rennie, L.F.; Kitching, R.P.; Mellor, P.S. Attempted mechanical transmission of Lumpy Skin Disease virus by biting insects. Med. Vet. Entomol. 2003, 17, 294-300. [CrossRef] [PubMed]

11. Tuppurainen, E.S.M.; Stoltsz, W.H.; Troskie, M.; Wallace, D.B.; Oura, C.A.L.; Mellor, P.S.; Coetzer, J.A.W.; Venter, E.H. A potential role for ixodid (hard) tick vectors in the transmission of Lumpy Skin Disease virus in cattle. Transbound. Emerg. Dis. 2011, 58, 93-104. [CrossRef] [PubMed] 
12. Tuppurainen, E.S.; Lubinga, J.C.; Wilhelm, J.C.; Stoltsz, H.; Troskie, M.; Carpenter, S.T.; Coetzer, J.A.W.; Venter, E.H.; Oura, A.L. Mechanical transmission of Lumpy Skin Disease virus by Rhipicephalus appendiculatus male ticks. Epidemiol. Infect. 2013, 141, 425-430. [CrossRef]

13. Lubinga, J.C.; Tuppurainen, E.S.; Coetzer, J.A.; Stoltsz, W.H.; Venter, E.H. Transovarial passage and transmission of LSDV by Amblyomma hebraeum, Rhipicephalus appendiculatus and Rhipicephalus decoloratus. Exp. Appl. Acarol. 2014, 62, 67-75. [CrossRef]

14. Sohier, C.; Haegeman, A.; Mostin, L.; De Leeuw, I.; Van Campe, W.; De Vleeschauwer, A.; Tuppurainen, E.; van den Berg, T.; De Regge, N.; De Clercq, K. Experimental evidence of mechanical Lumpy Skin Disease virus transmission by Stomoxys calcitrans biting flies and Haematopota spp. horseflies. Sci. Rep. 2019, 9, 1-10. [CrossRef] [PubMed]

15. Babiuk, S.; Bowden, T.R.; Parkyn, G.; Dalman, B.; Hoa, D.M.; Long, N.T.; Vu, P.P.; Bieu, D.X.; Copps, J.; Boyle, D.B. Yemen and Vietnam capripoxviruses demonstrate a distinct host preference for goats compared with sheep. J. Gen. Virol. 2009, 90, 105-114. [CrossRef] [PubMed]

16. Kreindel, S.; Masiulis, M.; Skrypnyk, A.; Zdravkova, A.; Escher, M.; Raizman, E. Emergence of lumpy skin disease in Asia and Europe. Empres Anim. Health 2016, 46, 360.

17. Hurisa, T.T.; Jing, Z.; Jia, H.; Chen, G.; He, X.B. A Review on Sheeppox and Goatpox: Insight of Epidemiology, Diagnosis, Treatment and Control Measures in Ethiopia. J. Infect. Dis. Epidemiol. 2018, 4, 057. [CrossRef]

18. Tuppurainen, E.S.; Galon, N. Lumpy Skin Disease: Current situation in Europe and neighbouring regions and necessary control measures to halt the spread in South-East Europe. Oie Reg. Comm. 2016.

19. Yeruham, I.; Nir, O.; Braverman, Y.; Davidson, M.; Grinstein, H.; Haymovitch, M.; Zamir, O. Spread of Lumpy Skin Disease in Israeli dairy herds. Vet. Rec 1995, 137, 91-93. [CrossRef] [PubMed]

20. Ayelet, G.; Abate, Y.; Sisay, T.; Nigussie, H.; Gelaye, E.; Jemberie, S.; Asmare, K. Lumpy Skin Disease: Preliminary vaccine efficacy assessment and overview on outbreak impact in dairy cattle at debre zeit, central Ethiopia. Antivir. Res. 2013, 98, 261-265. [CrossRef] [PubMed]

21. Ben-Gera, J.; Klement, E.; Khinich, E.; Stram, Y.; Shpigel, N.Y. Comparison of the efficacy of Neethling Lumpy Skin Disease virus and x10RM65 sheep-pox live attenuated vaccines for the prevention of Lumpy Skin Disease-The results of a randomized controlled field study. Vaccine 2015, 33, 4837-4842. [CrossRef] [PubMed]

22. Boumart, Z.; Daouam, S.; Belkourati, I.; Rafi, L.; Tuppurainen, E.; Tadlaoui, K.O.; El Harrak, M. Comparative innocuity and efficacy of live and inactivated sheeppox vaccines. BMC Vet. Res. 2016, 12, 133. [CrossRef]

23. Hamdi, J.; Boumart, Z.; Daouam, S.; El Arkam, A.; Bamouh, Z.; Jazouli, M.; Tadlaoui, O.K.; Fassi Fihri, O.; Gavrilov, B.; El Harrak, M. Development and Evaluation of an Inactivated Lumpy Skin Disease Vaccine for Cattle. Vet. Microbiol 2020, $245,108689$. [CrossRef] [PubMed]

24. Wolff, J.; Moritz, T.; Schlottau, K.; Hoffmann, D.; Beer, M.; Hoffmann, B. Development of a Safe and Highly Efficient Inactivated Vaccine Candidate against Lumpy Skin Disease Virus. Vaccines 2021, 9, 4. [CrossRef]

25. Yeruham, I.; Yadin, H.; Van Ham, M.; Bumbarov, V.; Soham, A.; Perl, S. Economic and epidemiological aspects of an outbreak of sheeppox in a dairy sheep flock. Vet. Rec 2007, 160, 236-237. [CrossRef] [PubMed]

26. Garner, M.G.; Sawarkar, S.D.; Brett, E.K.; Edwards, J.R.; Kulkarni, V.B.; Boyle, D.B.; Singh, S.N. The Extent and Impact of Sheep Pox and Goat Pox in the State of Maharashtra, India. Trop. Anim. Health Prod. 2000, 32, 205-223. [CrossRef] [PubMed]

27. Tuppurainen, E.S.M.; Oura, C.A.L. Review: Lumpy Skin Disease: An Emerging Threat to Europe, the Middle East and Asia. Trans. Emerg. Dis. 2012, 9, 40-48. [CrossRef] [PubMed]

28. Gari, J.G. Epidemiological Study of Lumpy Skin Disease and Its Economic Impact in Ethiopia. Ph.D. Thesis, Institut National Polytechnique de Toulouse, Toulouse, France, 2011.

29. Coetzer, J.A.W. Lumpy Skin Disease. In Infectious Diseases of Livestock; Coetzer, J.A.W., Tustin, R.C., Eds.; Oxford University Press: Oxford, UK, 2004; pp. 1268-1276.

30. Peck, D.; Bruce, M. The economic efficiency and equity of government policies on brucellosis: Comparative insights from Albania and the United States of America. Rev. Sci. Tech. Off. Int. Epiz 2017, 36, 291-302. [CrossRef]

31. Tuppurainen, E.; Babiuk, S.; Klement, E. Lumpy Skin Disease; Springer International Publishing AG: Berlin/Heidelberg, Germany, 2018.

32. Alemayehu, G.; Zewde, G.; Admassu, B. Risk assessments of Lumpy Skin Disease in Borena bull market chain and its implication for livelihoods and international trade. Trop. Anim. Health Prod. 2013, 45, 1153-1159. [CrossRef] [PubMed]

33. Hailu, B.; Alemayehu, G. Epidemiology, Economic Importance and Control Techniques of Lumpy Skin Disease: A review. InJAR 2015, 3, 197-205.

34. Joshi, R.K.; Chandra, R.; Rao, V.D.P.; Garg, S.K. Goatpox: A Review. J. Appl. Anim. Res. 1992, 2, 57-72. [CrossRef]

35. Biswas, S.; Noyce, R.S.; Babiuk, L.A.; Lung, O.; Bulach, D.M.; Bowden, T.R.; Boyle, D.B.; Babiuk, B.; Evans, D.H. Extended sequencing of vaccine and wild-type capripoxvirus isolates provides insights into genes modulating virulence and host range. Transbound. Emerg. Dis. 2019, 1-18. [CrossRef] [PubMed]

36. Van Regenmortel, M.H.V.; Fauquet, C.M.; Bishop, D.H.L. Virus Taxonomy: Seventh Report of the International Committee on Taxonomy of Viruses; Academic Press: Jerusalem, Israel, 1996.

37. Nagington, J. Electron Microscopy in Differential Diagnosis of Poxvirus Infections. Brit. Med. J. 1964, 2, 1499-1500. [CrossRef] 
38. Vilagines, P.; Vilagines, R. Les poxviridés: Caractères généraux. In Virologie Médicale; Maurin, J., Ed.; Presses Universitaires Lyon: Lyon, France, 1985; pp. 310-319.

39. Moss, B. Recombinant Poxviruses; CRC Press: Boca Raton, FL, USA, 1992; pp. 45-80.

40. McLysaght, A.; Baldi, P.F.; Gaut, B.S. Extensive gene gain associated with adaptive evolution of poxviruses. Proc. Natl. Acad. Sci. USA 2003, 100, 15655-15660. [CrossRef]

41. Hughes, A.L.; Friedman, R. Poxvirus genome evolution by gene gain and loss. Mol. Phylogenetics Evol. 2005, 35, 186-195. [CrossRef] [PubMed]

42. Bratke, K.A.; McLysaght, A. Identification of multiple independent horizontal gene transfers into poxviruses using a comparative genomics approach. BMC Evol. Biol. 2008, 8, 67. [CrossRef] [PubMed]

43. Tarbouriech, O.; Flusin, C.; Sele, F.; Iseni, F. La synthèse du génome des poxvirus. Virologie 2012, 16, $210-224$.

44. Moss, B. Poxviridae: The viruses and their replication. In Fields Virology; Knipe, D.M., Howley, P.M., Eds.; Lippincott Williams \& Wilkins: Philadelphia, PA, USA, 2007; pp. 2905-2946.

45. Tulman, E.R.; Afonso, C.L.; Lu, Z.; Zsak, L.; Kutish, G.F.; Rock, D.L. Genome of Lumpy Skin Disease Virus. J. Virol. 2001, 75, 7122-7130. [CrossRef]

46. Tulman, E.R.; Afonso, C.L.; Lu, Z.; Zsak, L.; Sur, J.H.; Sandybaev, N.T.; Kerembekova, U.Z.; Zaitsev, V.L.; Kutish, G.F.; Rock, D.L. The genomes of sheepox and goatpox viruses. J. Virol. 2002, 76, 6054-6061. [CrossRef]

47. Rouby, S.R. RPO30 Gene based PCR for Detection and Differentiation of Lumpy Skin Disease Virus and Sheep Poxvirus Field and Vaccinal Strains. Vet. Sci. Res. Rev. 2018, 4, 1-8. [CrossRef]

48. Chibssa, T.R.; Settypalli, T.B.K.; Berguido, F.J.; Grabherr, R.; Loitsch, A.; Tuppurainen, E.; Nwankpa, N.; Tounkara, K.; Madani, H.; Omani, A.; et al. An HRM Assay to Differentiate Sheepox Virus Vaccine Strains from Sheepox Virus Field Isolates and other Capripoxvirus Species. Sci. Rep. 2019, 9, 6646. [CrossRef]

49. Lamien, C.E.; Lelenta, M.; Goger, W.; Silber, R.; Tuppurainen, E.; Matijevic, M.; Luckins, A.G.; Diallo, A. Real time PCR method for simultaneous detection, quantitation and differentiation of Capripoxviruses. J. Virol. Methods 2011, 171, 134-140. [CrossRef]

50. Le Goff, C.; Lamien, C.E.; Fakhfakh, E.; Chadeyras, A.; Aba-Adulugba, E.; Libeau, G.; Tuppurainen, E.; Wallace, D.B.; Adam, T.; Silber, R.; et al. Capripoxvirus G-protein-coupled chemokine receptor: A host-range gene suitable for virus animal origin discrimination. J. Gen. Virol. 2009, 90, 1967-1977. [CrossRef]

51. Diallo, A.; Viljoen, G.J. Genus Capripoxvirus. In Poxviruses; Mercer, A.A., Schmidt, A., Weber, O., Eds.; Birkhäuser: Basel, Switzerland, 2007; pp. 167-181.

52. Hamdi, J.; Bamouh, Z.; Jazouli, M.; Alhyane, M.; Safini, N.; Tadlaoui, K.O.; Fassi Fihri, O.; El Harrak, M. Experimental infection of indigenous North African goats with goatpox virus. Acta Vet. Scand 2021, 63, 9. [CrossRef] [PubMed]

53. CFSPH, Iowa State University. Sheep \& Goat Pox. 2008. Available online: http://www.cfsph.iastate.edu/Factsheets/pdfs/ sheep_and_goat_pox.pdf (accessed on 19 February 2021).

54. Barnard, B.J.; Munz, E.; Dumbell, K.; Prozesky, L. Lumpy Skin Disease. In Infectious Diseases of Livestock with Special Reference to Southern Africa; Coetzer, J.A.W., Thomson, G.R., Tustin, R.C., Eds.; Oxford University Press: Oxford, UK, 1994.

55. Wolff, J.; Abd El Rahman, S.; King, J.; El-Beskawy, M.; Pohlmann, M.; Beer, M.; Hoffmann, B. Establishment of a Challenge Model for Sheeppox Virus Infection. Microorganisms 2020, 8, 2001. [CrossRef] [PubMed]

56. Gari, G.; Abie, G.; Gizaw, D.; Wubete, A.; Kidane, M.; Asgedom, H.; Tuppurainen, E.S.M. Evaluation of the safety, immunogenicity and efficacy of three capripoxvirus vaccine strains against Lumpy Skin Disease virus. Vaccine 2015, 33, 3256-3261. [CrossRef] [PubMed]

57. Hamdi, J.; Bamouh, Z.; Jazouli, M.; Boumart, Z.; Omari Tadlaoui, K.; Fassi Fihri, O.; El Harrak, M. Experimental evaluation of the cross-protection between Sheepox and bovine Lumpy skin vaccines. Sci. Rep. 2020, 10, 8888. [CrossRef]

58. Arsevska, E.; Bronner, A.; Calavas, D.; Cauchard, J.; Caufour, P.; Falala, S.; Hamon, M.; Hendrikx, P.l.; Lancelot, R.; Mercier, A.; et al. Dermatose nodulaire contagieuse des bovins: État des connaissances et situation épidémiologique dans les Balkans au 31 juillet 2016. Bull. Epid St. Anim Alim 2016, 75, 20-24.

59. Omar, R. Comparison of the Two Lumpy Skin Disease Virus Vaccines, Neethling and Herbivac, and Construction of a Recombinant Herbivac-Rift Valley Fever Virus Vaccine. Master's Thesis, University of Cape Town, Cape Town, South Africa, 2015.

60. Smith, S.A.; Kotwal, G.J. Immune Response to Poxvirus Infections in Various Animals. Crit. Rev. Microbiol. 2002, 28, 149-185. [CrossRef]

61. Aristizábal, B.; González, A. Innate immune system. In Autoimmunity: From Bench to Bedside; Anaya, J.M., Shoenfeld, Y., Rojas-Villarraga, A., Eds.; El Rosario University Press: Bogota, Colombia, 2013.

62. Moutaftsi, M.; Tscharke, D.C.; Vaughan, K.; Koelle, D.M.; Stern, L.; Calvo-Calle, M.; Ennis, F.; Terajima, M.; Sutter, G.; Crotty, S.; et al. Uncovering the interplay between CD8, CD4 and antibody responses to complex pathogens. Future Microbiol. 2010, 5, 221-239. [CrossRef]

63. Bonilla, F.A.; Oettgen, H.C. Adaptative immunity. J. Allergy Clin. Immunol. 2010, 125, 33-40. [CrossRef] [PubMed]

64. Marshall, J.S.; Warrington, R.; Watson, W.; Kim, H.L. An introduction to immunology and immunopathology. Allergy Asthma Clin. Immunol. 2018, 14, 49. [CrossRef]

65. Milovanović, M.; Dietze, K.; Milićević, V.; Radojičić, S.; Valčić, M.; Moritz, T.; Hoffman, B. Humoral immune response to repeated lumpy skin disease virus vaccination and performance of serological tests. BMC Vet. Res. 2019, 15, 80. [CrossRef] 
66. Samojlović, M.; Polacek, V.; Gurjanov, V.; Lupulovic, D.; Lazic, G.; Petrovic, T.; Lazic, S. Detection of antibodies against Lumpy skin disease virus by Virus neutraliza-tion test and ELISA methods. Acta Vet. Beogr. 2019, 69, 47-60. [CrossRef]

67. Kitching, R.P.; Bhat, P.P.; Black, D.N. The characterization of African strains of capripoxvirus. Epidemiol. Infect. 1989, 102, 335-343. [CrossRef] [PubMed]

68. Carn, V.M. Control of capripoxvirus infections. Vaccine 1993, 11, 1275-1279. [CrossRef]

69. Seet, B.T.; Johnston, J.B.; Brunetti, C.R.; Barrett, J.W.; Everett, H.; Cameron, C.; Sypula, J.; Nazarian, S.H.; Lucas, A.; McFadden, G. Poxviruses and immune evasion. Annu. Rev. Immunol. 2003, 21, 377-423. [CrossRef]

70. Norian, R.; Ahangaran, N.A.; Varshovi, H.R.; Azadmehr, A. Evaluation of humoral and cell-mediated immunity of two capripoxvirus vaccine strains against Lumpy Skin Disease virus. Iran. J. Virol. 2016, 10, 1-11. [CrossRef]

71. Varshovi, H.R.; Norian, R.; Azadmehr, A.; Afzal Ahangaran, N. Immune response characteristics of Capri pox virus vaccines following emergency vaccination of cattle against Lumpy Skin Disease virus. IJVST 2017, 9, 33-40.

72. Alberts, B. T Cells and MHC Proteins. In Molecular Biology of the Cell, 4th ed.; Garland Science: New York, NY, USA, 2002.

73. Bray, M.; Wright, M.E. Progressive vaccinia. Clin Infect. Dis. 2003, 36, 766-774. [CrossRef]

74. Belyakov, I.M.; Earl, P. Shared modes of protection against poxvirus infection by attenuated and conventional smallpox vaccine viruses. Proc. Natl. Acad. Sci. USA 2003, 100, 9458-9463. [CrossRef]

75. Xu, R.; Johnson, A. Cellular and humoral immunity against vaccinia virus infection of mice. J. Immunol. 2004, 172, 6265. [CrossRef]

76. Fang, M.; Sigal, L. Antibodies and CD8+ T cells are complementary and essential for natural resistance to a highly lethal cytopathic virus. J. Immunol. 2005, 175, 6829. [CrossRef]

77. Edghill-Smith, Y.; Bray, M. Smallpox vaccine does not protect macaques with AIDS from a lethal monkeypox virus challenge. J. Infect. Dis. 2005, 191, 372-381. [CrossRef]

78. Fenner, F.; Anderson, D.A.; Arita, I.; Jezek, Z.; Ladnyi, I.D. Smallpox and Its Eradication; World Health Organization: Geneva, Switzerland, 1988.

79. Redfield, R.R.; Wright, D.C. Disseminated vaccinia in a military recruit with human immunodeficiency virus (HIV) disease. N Engl. J. Med. 1987, 316, 673-676. [CrossRef] [PubMed]

80. Panchanathan, V.; Chaudhri, G.; Karupiah, G. Correlates of protective immunity in poxvirus infection: Where does antibody stand? Immunol. Cell Biol. 2008, 86, 80-86. [CrossRef]

81. Kennedy, J.S.; Frey, S.E.; Yan, L.; Rothman, A.L.; Cruz, J.; Newman, F.K.; Orphin, L.; Belshe, R.B.; Ennis, F.A. Induction of Human T Cell-Mediated Immune Responses after Primary and Secondary Smallpox Vaccination. JID 2004, 190, 1286-1294. [CrossRef]

82. Hammarlund, E.; Lewis, M.W.; Hansen, S.G. Duration of antiviral immunity after smallpox vaccination. Nat. Med. 2003, 9, 1131-1137. [CrossRef] [PubMed]

83. Hsieh, S.M.; Pan, S.C.; Chen, S.Y.; Huang, P.F.; Chang, S.C. Age distribution for T cell reactivity to vaccinia virus in a healthy population. Clin. Infect. Dis. 2004, 38, 86-89. [CrossRef] [PubMed]

84. Crotty, S.; Felgner, P.; Davies, H.; Glidewell, J.; Villarreal, L.; Ahmed, R. Cutting edge: Long-term B cell memory in humans after smallpox vaccination. J. Immunol. 2003, 171, 4969-4973. [CrossRef] [PubMed]

85. Putz, M.M.; Alberini, I.; Midgley, C.M.; Manini, I.; Montomoli, E.; Smith, G.L. Prevalence of antibodies to Vaccinia virus after smallpox vaccination in Italy. J. Gen. Virol. 2006, 86, 2955-2960. [CrossRef] [PubMed]

86. Agianniotaki, E.I.; Babiuk, S.; Katsoulos, P.D.; Chaintoutis, S.C.; Praxitelous, A.; Quizon, K.; Boscos, C.; Polizopoulou, Z.S.; Chondrokouki, E.D.; Dovas, C.I. Colostrum transfer of neutralizing antibodies against lumpy skin disease virus from vaccinated cows to their calves. Transbound. Emerg. Dis. 2018, 65, 2043-2048. [CrossRef] [PubMed]

87. Weiss, K.E. Lumpy Skin Disease. Virol. Monogr. 1968, 3, 111-131.

88. Precausta, P.; Kota, F.; Vellut, G. A new freeze-dried living virus vaccine against sheep pox. Comp. Immunol. Microbiol. Infect. Dis. 1979, 1, 305-319. [CrossRef]

89. Gitao, C.G.; Mbindyo, C.; Omani, R.; Chemweno, V. Review of Sheep Pox Disease in Sheep. J. Vet. Med. Res. $2017,4,1068$.

90. Gulyaz, V. Investigation of immunity in lambs born to ewes vaccinated with sheep and goat pox vaccine. Pendik Veteriner Mikrobiyoloji Dergisi 1999, 30, 55-62.

91. Rodriguez, J.F.; Janeczko, R.; Esteban, M. Isolation and characterization of neutralizing monoclonal antibodies to vaccinia virus. J. Virol. 1985, 56, 482-488. [CrossRef] [PubMed]

92. Gordon, J.; Mohandas, A.; Wilton, S.; Dales, S. A prominent antigenic surface polypeptide involved in the biogenesis and function of the vaccinia virus envelope. Virology 1991, 181, 671-686. [CrossRef]

93. Hsiao, J.C.; Chung, C.S.; Chang, W. Vaccinia virus envelope D8L protein binds to cell surface chondroitin sulfate and mediates the adsorption of intracellular mature virions to cells. J. Virol 1999, 73, 8750-8761. [CrossRef] [PubMed]

94. EFSA Panel on Animal Health and Welfare (AHAW). Scientific Opinion on sheep and goat pox. EFSA J. 2014, 12, 3885. [CrossRef]

95. EFSA Panel on Animal Health and Welfare (AHAW). Scientific Opinion on Lumpy Skin Disease. EFSA J. 2015, $13,3986$.

96. Munyanduki, H.M. Improvement of the Capripoxvirus, lumpy Skin Disease Virus for Use as a Vaccine Vector. Ph.D. Thesis, Faculty of Health Sciences Department of Pathology, University of Cape Town, Cape Town, South Africa, 2018. Available online: http:/ / hdl.handle.net/11427/30034 (accessed on 19 February 2021).

97. Kalra, S.K.; Sharma, V.K. Adaptation of Jaipur strain of sheeppox virus in primary lamb testicular cell culture. Indian J. Exp. Biol. 1981, 19, 165-169. 
98. Das, S.K.; Pandey, A.K.; Mallick, B.B. A nore on rhe nat-ural goat pox outbreak in Garwal Hills of Uttar Pradesh. Indian Vet. J. 1978, 55, 671-673.

99. Van Rooyen, P.J.; Munz, E.K.; Weiss, K.E. The optimal conditions for the multi-plication of Neethling-type Lumpy Skin Disease virus in embryonated eggs. Onderstepoort J. Vet. Res. 1969, 36, 165-174.

100. Bhanuprakash, V.; Hosamani, M.; Juneja, S.; Kumar, N.; Singh, R.K. Detection of goat pox antibodies, comparative efficacy of indirect ELISA and ounterimmunoelectrophoresis. J. Appl. Anim. Res. 2006, 30, 177-180. [CrossRef]

101. Ramyar, H.; Hessami, M. Development of an attenuated live vaccine against sheep-pox. Arch. Inst. Razi 1968, 20, 77-80. [CrossRef] [PubMed]

102. Martin, W.B.; Ergm, H.; Koylu, A. Tests on sheep of attenuated sheep pox vaccines. Res. Vet. Sci. 1973, 14, 53. [CrossRef]

103. Penkova, V.M.; Jasslm, F.A.; Thompson, J.R.; AI-Doon, T.M. The propagation of an attenuated sheep pox virus and its use as a vaccine. Bull. Off. Int. Eptzoot. 1974, 81, 329-339.

104. Mateva, V.; Stoichev, S. Adaptation and cultivation of sheep-pox virus (strain Perego) in tissue cultures and evaluation of its immunogenic properties. Vet. Nauk. 1975, 12, 18-23.

105. Anandan, R.; Sundara Rajan, S.; Kannamani, G.; Jayaraman, M.S. Studies on live and inactivated sheep pox vaccines. Cherion 1972, 1, 42-55.

106. Abbas, F.; Khan, F.A.; Hussain, A.; Ahmed, F.; Ahmed, M.; Ahmed, S.; Ahmed, M.Z.; Attique, M.A.; Wadood, A.; Taj, M.K. Production of goatpox virus vaccine from a live attenuated goatpox virus strain. J. Anim. Plant Sci. 2010, $20,315-317$.

107. Hosamani, M.; Nandi, S.; Mondal, B.; Singh, R.K.; Rasool, T.J.; Bandyopadhyay, S.K. A vero cell-attenuated goat pox virus provides protection against virulent virus challenge. Acta Virol. 2004, 48, 15-21. [PubMed]

108. Dubey, S.C.; Sawhney, A.M. Live and reactivated tissue culture vaccines against goat pox. Indian Vet. J. 1978, $55,925$.

109. Capstick, P.B.; Prydle, J.; Coackley, W.; Burdm, M.L. Protection of cattle against the Neethhng type virus of lumpy skin disease. Vet. Rec. 1959, 71, 422-423.

110. Davies, F.G.; Mbugwa, G. The alterations in pathogenicity and immunogenicity of a Kenya sheep and goat pox virus on serial passage in bovine foetal cell cultures. J. Comp. Pathol. 1985, 95, 565-572. [CrossRef]

111. Davies, F.G. Characteristics of a virus causing a pox disease in sheep and goats on Kenya, with observations on the epidemiology and control. J. Hyg. (Camb.) 1976, 76, 163-171. [CrossRef] [PubMed]

112. Kitching, R.P.; Smale, C. Comparison of the external dimensions of capripoxvirus isolates. Res. Vet. Sci. 1986, $41,425-427$. [CrossRef]

113. Chaudhary, S.S.; Pandey, K.D.; Singh, R.P.; Verma, P.C.; Gupta, P.K. A Vero cell derived combined vaccine against sheep pox and Peste des petits ruminants for sheep. Vaccine 2009, 27, 2548-2553. [CrossRef] [PubMed]

114. Yogisharadhya, R.; Bhanuprakash, V.; Hosamani, M.; Venkatesan, G.; Balamurugan, V.; Bora, D.P.; Bhanot, V.; Prabhu, M.; Singh, R.K. Comparative efficacy of live replicating sheepox vaccine strains in Ovines. Biologicals 2011, 39, 417-423. [CrossRef]

115. Sevik, M.; Dogan, M. Epidemiological and Molecular Studies on Lumpy Skin Disease Outbreaks in Turkey during $2014-2015$. Transbound. Emerg. Dis. 2016, 64, 1268-1279. [CrossRef]

116. Kitching, R.P. Vaccines for Lumpy Skin Disease, Sheep Pox and Goat Pox. Vaccines for OIE List A and Emerging Animal Diseases. In Proceedings of the Symposium, Ames, IA, USA, 16-18 September 2003; pp. 161-167.

117. Le Goff, C.; Fakhfakh, E.; Chadeyras, A.; Aba-Adulugba, E.; Libeau, G.; Hammami, S.; Diallo, A.; Albina, E. Host-range phylogenetic grouping of capripoxviruses: Genetic typing of CaPVs. In Applications of Gene-Based Technologies for Improving Animal Production and Health in Developing Countries; Makkar, H.P.S., Viljoen, G.J., Eds.; Springer: Berlin/Heidelberg, Germany, 2005; pp. 727-733.

118. Tuppurainen, E.S.M.; Pearson, C.R.; Bachanek-Bankowska, K.; Knowles, N.J.; Amareen, S.; Frost, L.; Henstock, M.R.; Lamien, C.E.; Diallo, A.; Mertens, P.P.C. Characterization of sheep pox virus vaccine for cattle against Lumpy Skin Disease virus. Antivir. Res. 2014, 109, 1-6. [CrossRef]

119. Kara, P.D.; Afonso, C.L.; Wallace, D.B.; Kutish, G.F.; Abolnik, C.; Lu, Z.; Vreede, F.T.; Taljaard, L.C.F.; Zsak, A.; Viljoen, G.J.; et al. Comparative sequence analysis of the South African vaccine strain and two virulent field isolates of Lumpy Skin Disease virus. Arch. Virol. 2003, 148, 1335-1356. [CrossRef]

120. Mathijs, E.; Vandenbussche, F.; Haegeman, A.; King, A.; Nthangeni, B.; Potgieter, C.; Maartens, L.; Van Born, S.; De Clercq, K. Complete genome sequences of the Neethling-Like Lumpy Skin Disease virus strains obtained directly from three com-mercial live attenuated vaccines. Genome Announc. 2016, 4, e01255-16. [CrossRef]

121. Katsoulos, P.D.; Chaintoutis, S.C.; Dovas, C.I.; Polizopoulou, Z.S.; Brellou, G.D.; Agianniotaki, E.I.; Tasioudi, K.E.; Chondrokouki, E.; Papadopoulos, O.; Karatzias, H.; et al. Investigation on the incidence of adverse reactions, viraemia and haematological changes following field immunization of cattle using a live attenuated vaccine against Lumpy Skin Disease. Transbound. Emerg. Dis. 2018, 65, 174-185. [CrossRef]

122. European Food Safety Authority (EFSA). Lumpy Skin Disease: I. Data collection and analysis. EFSA J. 2017, 15, 4773. [CrossRef]

123. European Food Safety Authority (EFSA); Calistri, P.; DeClercq, K.; Gubbins, S.; Klement, E.; Stegeman, A.; Cortinas Abrahantes, J.; Antoniou, S.E.; Broglia, A.; Gogin, A. Scientific report on Lumpy Skin Disease: III. Data collection and analysis. EFSA J. 2019, 17, 5638. [CrossRef] 
124. Agianniotaki, E.I.; Chaintoutis, S.C.; Haegeman, A.; Tasioudi, K.E.; De Leeuw, I.; Katsoulos, P.D.; Sachpatzidis, A.; De Clercq, K.; Alexandropoulos, T.; Polizopoulou, Z.S.; et al. Development and validation of a TaqMan probe-based real-time PCR method for the differentiation of wild type Lumpy Skin Disease virus from vaccine virus strains. J. Virol. Methods 2017, 249, 48-57. [CrossRef]

125. Bedekovic, T.; Simic, I.; Kresic, N.; Lojkic, I. Detection of Lumpy Skin Disease virus in skin lesions, blood, nasal swabs and milk following preventive vaccination. Transbound. Emerg. Dis. 2017, 65, 491-496. [CrossRef] [PubMed]

126. Yeruham, I.; Perl, S.; Nyska, A.; Abraham, A.; Davidson, M.; Haymovitch, M.; Zamir, O.; Grinstein, H. Adverse reactions in cattle to a capripox vaccine. Vet. Rec. 1994, 135, 330-332. [CrossRef] [PubMed]

127. Salib, F.A.; Osman, A.H. Incidence of Lumpy Skin Disease among Egyptian cattle in Giza Governorate, Egypt. Vet. World 2011, 4, 162-167.

128. Kitching, R.P.; Hammond, J.M.; Taylor, W.P. A single vaccine for the control of capripox infection in sheep and goats. Res. Vet. Sci. 1987, 42, 53-60. [CrossRef]

129. Achour, H.A.; Bouguedour, R.; Bouhbal, A.; Guechtouli, A.; Aouissat, M. Étude comparative du pouvoir immunisant de quelques souches atténuées de virus de la clavelée et d'un vaccin sensibiliser. Rev. Sci. Tech. Oie 2000, 19, 773-783. [CrossRef]

130. Bhanuprakash, V.; Hosamani, M.; Singh, R.K. Prospects of control and eradication of capripox from the Indian subcontinent: A perspective. Antivir. Res. 2011, 91, 225-232. [CrossRef] [PubMed]

131. Awad, M.; Michael, A.; Soliman, S.M.; Samir, S.S.; Daoud, A.M. Trials for preparation of inactivated sheep pox vaccine using binary ethyleneimine. Egypt. J. Immunol. 2003, 10, 67-72.

132. Kadymov, R.A. Combined immunization of sheep against anthrax, sheep pox and clostridial infections. Vet. Mosc. 1975, 2, 50-52.

133. Selyaninov, Y.O.; Balyshev, V.M.; Kosyachenko, N.S.; Egorova, I.Y. Experimental assessment of the efficacy of associated vaccine against anthrax and sheep pox. Russ. Agric. Sci. 2003, 43-45.

134. Hosamani, M.; Singh, S.K.; Mondal, B.; Sen, A.; Bhanuprakash, V.; Bandyopadhyay, S.K.; Yadav, M.P.; Singh, R.K. A bivalent vaccine against goat pox and peste des petits ruminants induces protective immune response in goats. Vaccine 2006, 24, 6058-6064. [CrossRef]

135. Fakri, F.; Ghzal, F.; Daouam, S.; Elarkam, A.; Douieb, L.; Zouheir, Y.; Tadlaoui, K.; Fassi-Fihri, O. Development and field application of a new combined vaccine against Peste des Petits Ruminants and Sheep Pox. Trials Vaccinol. 2015, 4, 33-37. [CrossRef]

136. Fakri, F.Z.; Embarki, T.; Baha, W.; Tadlaoui, K.O.; Fihri, O.F. Large mass vaccination of small ruminants against Peste des Petits Ruminants and Sheeppox using a combined live attenuated vaccine. J. Vet. Med. Res. 2020, 7, 1200.

137. Wallace, D.; Ellis, C.; Espach, A.; Smith, S.; Greyling, R.; Viljoen, G. Protective immune responses induced by different recombinant vaccine regimes to Rift Valley Fever. Vaccine 2006, 24, 7181-7189. [CrossRef]

138. Wallace, D.B.; Mather, A.; Kara, P.D.; Naicker, L.; Mokoena, N.B.; Pretorius, A.; Nefefe, T.; Thema, N.; Babiuk, S. Protection of Cattle Elicited Using a Bivalent Lumpy Skin Disease Virus-Vectored Recombinant Rift Valley Fever Vaccine. Front. Vet. Sci. 2020, 7, 256. [CrossRef]

139. Diallo, A.; Minet, C.; Berhe, G.; Le Goff, C.; Black, D.N.; Fleming, M.; Barrett, C.; Libeau, G. Goat immune response to Capripox vaccine expressing the hemagglutinin protein of Pest des Petits Ruminants. Ann. N. Y. Acad. Sci. 2002, 969, 88-91. [CrossRef] [PubMed]

140. Chen, W.; Hu, S.; Qu, L.; Hu, Q.; Zhang, Q.; Zhi, H.; Huang, K.; Bu, Z. A goat poxvirus-vectored peste-des-petits-ruminants vaccine induces long-lasting neutralization antibody to high levels in goats and sheep. Vaccine 2010, 28, 4742-4750. [CrossRef]

141. Fakri, F.; Bamouh, Z.; Ghzal, F.; Baha, W.; Tadlaoui, K.; Fihri, O.F.; Elharrak, M. Comparative evaluation of three capripoxvirusvectored peste des petits ruminants vaccines. Virology 2018, 514, 211-215. [CrossRef] [PubMed]

142. Zhang, M.; Sun, Y.; Chen, W.; Bu, Z. The 135 gene of goatpox virus encodes an inhibitor of NF-kappaB and apoptosis and may serve as an improved insertion site to generate vectored live vaccine. J. Virol. 2018, 92. [CrossRef] [PubMed]

143. Romero, C.H.; Barrett, T.; Evans, S.A.; Kitching, R.P.; Gershon, P.D.; Bostock, C.; Black, D.N. Single Capripoxvirus recombinant vaccine for the protection of cattle against Rinderpest and Lumpy Skin Disease. Vaccine 1993, 11, 737-742. [CrossRef]

144. Wade-Evans, A.M.; Romero, C.H.; Mellor, P.; Takamatsu, H.; Anderson, J.; Thevasagayam, J.; Fleming, M.J.; Mertens, P.P.; Black D.N. Expression of the major core structural protein (VP7) of bluetongue virus, by a recombinant capripox virus, provides partial protection of sheep against a virulent heterotypic bluetongue virus challenge. Virology 1996, 220, 227-231. [CrossRef]

145. Perrin, A.; Albina, E.; Bréard, E.; Sailleau, C.; Promé, S.; Grillet, C.; Kwiatek, O.; Russo, P.; Thiéry, R.; Zientara, S.; et al. Recombinant capripoxviruses expressing proteins of bluetongue virus: Evaluation of immune responses and protection in small ruminants. Vaccine 2007, 25, 6774-6783. [CrossRef]

146. Ma, W.; Wei, J.; Wei, Y.; Guo, H.; Jin, Y.; Xue, Y.; Wang, Y.; Yi, Z.; Liu, L.; Huang, J.; et al. Immunogenicity of the capsid precursor and a nine-amino-acid site-directed mutant of the $3 \mathrm{C}$ protease of foot-and-mouth disease virus coexpressed by a recombinant goatpox virus. Arch. Virol. 2014, 159, 1715-1722. [CrossRef] [PubMed]

147. Liu, F.; Fan, X.; Li, L.; Ren, W.; Han, X.; Wu, X.; Wang, Z. Development of recombinant goatpox virus expressing Echinococcus granulosus EG95 vaccine antigen. J. Virol. Methods 2018, 261, 28-33. [CrossRef]

148. Sun, Z.; Liu, L.; Zhang, H.; Li, Y.; Wei, F.; Li, Z.; Wang, P.; Fu, Q.; Ren, Y.; Zhang, Y.; et al. Expression and functional analysis of Brucella outer membrane protein 25 in recombinant goat pox virus. Mol. Med. Rep. 2019, 19, 2323-2329. [CrossRef] 
149. Boshra, H.; Truong, T.; Nfon, C.; Bowden, T.R.; Gerdts, V.; Tikoo, S.; Babiuk, L.A.; Kara, P.; Mather, A.; Wallace, D.B.; et al. A lumpy skin disease virus deficient of an IL-10 gene homologue provides protective immunity against virulent capri-poxvirus challenge in sheep and goats. Antivir. Res. 2015, 123, 39-49. [CrossRef]

150. Molla, W.; Frankena, K.; Gari, G.; Kidane, M.; Shegu, D.; de Jong, M.C.M. Seroprevalence and risk factors of lumpy skin disease in Ethiopia. Prev. Vet. Med. 2018, 160, 99-104. [CrossRef] [PubMed]

151. Haegeman, A.; De Leeuw, I.; Mostin, L.; Van Campe, W.; Aerts, L.; Vastag, M.; De Clercq, K. An Immunoperoxidase Monolayer Assay (IPMA) for the detection of lumpy skin disease antibodies. J. Virol. Methods 2019, 113800. [CrossRef]

152. Haegeman, A.; De Vleeschauwer, A.; De Leeuw, I.; Vidanović, D.; Šekler, M.; Petrović, T.; Demarez, C.; Lefebvre, D.; De Clercq, K. Overview of diagnostic tools for Capripox virus infections. Prev. Vet. Med. 2019. [CrossRef] [PubMed]

153. Kitching, R.P. Progress towards sheep and goat pox vaccines. Vaccine 1983, 1, 4-9. [CrossRef]

154. Haqiqi, S.; Hedayati, Z.; Varshuei, H.R.; Aqa Ebrahimiyan, M.; Khedmati, K.A.D. Study of Safety and Immunogenicity of Goat Pox Vaccine against Sheep Pox in Susceptible Sheep; Agricultural Scientific Information and Documentation Centre, Agricultural Research and Education Organization: Tehran, Iran, 2008.

155. Capstick, P.B.; Cocackley, W. Protection of Cattle against Lumpy Skin Disease. I. Trials with a vaccine against Neethling type infection. Cab Rev. Perspect. Agric. Vet. Sci. Nutr. Nat. Resour. 1961, 2, 362-368.

156. Brenner, J.; Bellaiche, M.; Gross, E.; Elad, D.; Oved, Z.; Haimo-vitz, M.; Wasserman, A.; Friedgut, O.; Stram, Y.; Bumbarov, V.; et al. Appearance of skin lesions in cattle populations vaccinated against Lumpy Skin Disease: Statutory challenge. Vaccine 2009, 27, 1500-1503. [CrossRef]

157. Solyom, F.; Perenlei, L.; Roith, J. A live a enuated virus vaccine against sheep pox. Acta Vet. Acad. Scient Hung. 1980, $28,389$.

158. Abd-Elfatah, E.B.; El-Mekkawi, M.F.; Aboul-Soud, E.A.; Fawzi, E.M.; El-Soally, S.A. Immunological response of a new trivalent capripoxvirus vaccine in pregnant ewes and does. Slov. Vet. Res. 2019, 56 (Suppl. 22), 445-455. [CrossRef]

159. Prasad, I.J.; Datt, N.S. Observation on the use of live and inactivated vaccines ag inst goat pox. Indian Vet. J. 1973, 50, 1-10.

160. Abu-Elzein, E. Observations on natural and experimental infection of sheep and goats with a virulent field Capripoxvirus with high affinity to goats. Vet. Arshiv 2003, 73, 119-131.

161. Abutarbush, S.M.; Hananeh, W.M.; Ramadan, W.; Al Sheyab, O.M.; Alnajjar, A.R.; Al Zoubi, I.G.; Knowles, N.J.; BachanekBankowsa, K.; Tuppurainen, E.S.M. Adverse reactions to field vaccination against Lumpy Skin Disease in Jordan. Transbound. Emerg. Dis. 2016, 63, 213-219. [CrossRef]

162. Ali, A.A.; Esmat, M.; Attia, H.; Selim, A.; Abdel-Hamid, Y.M. Clinical and patho-logical studies on Lumpy Skin Disease in Egypt. Vet. Rec. 1990, 127, 549-550.

163. Abdallah, F.M.; El Damaty, H.M.; Kotb, G.F. Sporadic cases of Lumpy Skin Disease among cattle in Sharkia province, Egypt: Genetic characterization of Lumpy Skin Disease virus isolates and pathological findings. Vet. World 2018, 11, 1150-1158. [CrossRef] [PubMed]

164. Zeedan, G.S.G.; Mahmoud, A.H.; Abdalhamed, A.B.; Abd El-Razik, K.A.E.; Khafagi, M.H.; Abou Zeina, H.A.A. Detection of Lumpy Skin Disease virus in cattle using real-time polymerase chain reaction and serological diagnostic assays in different governorates in Egypt in 2017. Vet. World 2019, 12, 1093-1100. [CrossRef]

165. Norian, R.; Afzal Ahagran, N.; Varshovi, H.R.; Azadmehr, A. Comparative efficacy of two heterologous capripox vaccines to control Lumpy Skin Disease in cattle. Bulg. J. Vet. Med. 2017, 22, 171-179. [CrossRef]

166. Mikhael, C.A.; Ibrahim, M.M.; Saad, M.A. Efficacy of Alternative Vaccination with Attenuated Sheep Pox and Inactivated Lumpy Skin Disease Vaccines against Lumpy Skin Disease. SCVMJ 2016, 21, 125-142. [CrossRef]

167. Mikhael, C.A.; Nakhla, O.E.; Mohamed, N.A. Study on the capability of a dual capripox vaccine in protection of cattle against LSD infection. J. Vet. Med. Res. 2017, 24, 224-233. [CrossRef]

168. Aboul-Soud, E.A.; Kafafy, M.H.; El-Suall, S.A.; Zaghloul, M.A.; Mikhael, C.A. Preparation of trivalent vaccine against Lumpy Skin Disease using different capripox viral strain. Int. J. Vet. Sci. Med. 2018, in press.

169. Zhugunissov, K.; Bulatov, Y.; Orynbayev, M.; Kutumbetov, L.; Abduraimov, Y.; Shayakhmetov, Y.; Taranov, D.; Amanova, Z.; Mambetaliyev, M.; Absatova, Z.; et al. Goatpox virus (G20-LKV) vaccine strain elicits a protective response in cattle against Lumpy Skin Disease at challenge with Lumpy Skin Disease virulent field strain in a comparative study. Vet. Microbiol. 2020, 245, 108695. [CrossRef] 